\title{
Regions identity between the genome of vertebrates and non-retroviral families of insect viruses
}

\author{
Gaowei Fan ${ }^{1,2}$ and Jinming $L i^{1,2^{*}}$
}

\begin{abstract}
Background: The scope of our understanding of the evolutionary history between viruses and animals is limited. The fact that the recent availability of many complete insect virus genomes and vertebrate genomes as well as the ability to screen these sequences makes it possible to gain a new perspective insight into the evolutionary interaction between insect viruses and vertebrates. This study is to determine the possibility of existence of sequence identity between the genomes of insect viruses and vertebrates, attempt to explain this phenomenon in term of genetic mobile element, and try to investigate the evolutionary relationship between these short regions of identity among these species.

Results: Some of studied insect viruses contain variable numbers of short regions of sequence identity to the genomes of vertebrate with nucleotide sequence length from $28 \mathrm{bp}$ to $124 \mathrm{bp}$. They are found to locate in multiple sites of the vertebrate genomes. The ontology of animal genes with identical regions involves in several processes including chromatin remodeling, regulation of apoptosis, signaling pathway, nerve system development and some enzyme-like catalysis. Phylogenetic analysis reveals that at least some short regions of sequence identity in the genomes of vertebrate are derived the ancestral of insect viruses.

Conclusion: Short regions of sequence identity were found in the vertebrates and insect viruses. These sequences played an important role not only in the long-term evolution of vertebrates, but also in promotion of insect virus. This typical win-win strategy may come from natural selection.
\end{abstract}

\section{Background}

The interaction between viruses and animals is quite profound and complex. Precious studies have deeply increased the depth of our understanding of their longterm evolutionary history in terms of genome sequence. Viruses have a highly host-associated life circle. As a result, they infect and occasionally integrate into the germ line cells chromosome and are inherited vertically as host alleles [1,2]. A growing number of nucleotide sequences of viruses have been and continue to be found in their respective host spices. These remnants of ancient viral infections play an important role in offering not only unforeseen sources of genomic novelty in their hosts $[1,3]$ but also molecular fossils to facilitate our

\footnotetext{
* Correspondence: ljm63hn@yahoo.com.cn

${ }^{1}$ National Center for Clinical Laboratories, Beijing Hospital, Beijing 100730, China

Full list of author information is available at the end of the article
}

knowledge of the evolution process between viruses and animals [4]. Some of these sequences identity in host species were found to highlight several pathways including cell adhesion, Wnt signalling[5] and immunomodulation [6] as well as mammalian reproduction [7].

However, most of these discoveries were merely addressed in an aspect of virus-host interaction and may narrow our prospective to probe the links between viruses and animals.

Here in a broad sense, we aimed at to identify the possible regions identity between the genomes of vertebrates and non-retroviral families of insect viruses and the possible role(s) of the identical sequences in evolution of the corresponding animal(s). Moreover, we reported phylogenetic analysis of these identical sequences. In this paper, we showed that at least some of the sequences identity in vertebrates chromosomes
C Biomed Central

(c) 2011 Fan and Li; licensee BioMed Central Ltd. This is an Open Access article distributed under the terms of the Creative Commons Attribution License (http://creativecommons.org/licenses/by/2.0), which permits unrestricted use, distribution, and reproduction in any medium, provided the original work is properly cited. 
identified here are likely to come from insect viruses and exapted during their long-term evolution.

\section{Results}

We screened several hundreds of insect viruses including DNA viruses and RNA viruses against 21 vertebrates. Of interest, dozens of short regions of sequence identity were found between animals and viruses including double stranded DNA viruses and double stranded RNA viruses (Table 1). Note that in our study more short regions of sequence identity to a DNA-virus were found than that to a RNA-virus which was also reported in precious study [8]. Ranging from $28 \mathrm{bp}$ to $124 \mathrm{bp}$, these sequences identity were found in two possible orientations in the respective animals. Most of these regions were found in intergenic regions of the genomes, some were within introns. However, with occasional exception, regions of identity were also found within gene-coding region. For example, in the case of duck-billed platypus, sequence identity to Phthorimaea operculella granulovirus occured within exon and coded protein similar to ubiquitin. Pieces of sequence identity that copy themselves and reinsert into the genome of animals could be found in our study. Besides, two distinct short regions of sequence identity to a certain virus also occurred in the same genome of the animal suggesting that more than one distinct short region derived from a virus invaded and fixed into the same animal genome. For example, in the case of zebra finch two distinct short regions identity to Choristoneura occidentalis granulovirus were found within the genome [GenBank:NW_002197778.1] with respective E-values $4 \mathrm{e}-23$ and $1 \mathrm{e}-14$.

\section{The relationship between pseudo-genes and sequences identity}

The phenomenon that a large number of identified regions were located near or within pseudo-genes caused our attention and promoted us to investigate what the relationship between the sequences identity and pseudo-genes was. To investigate this phenomenon further, we calculated the distance between the pseudo-genes and the end (s) of the regions identity as described in Methods.

Figure 1 shows the relationship between the distance from the ends of a short region of identity to the related pseudo-gene and the percentage of pseudo-gene within the distance. In our study, 7 out of 76 pseudo-genes harbor short regions of sequence identity. A rough rule of the distribution is that most of the pseudo-genes are within $1000 \mathrm{~kb}$ flanking the ends of the short regions of identity.

\section{Roles of genes containing sequences identity}

Table 2 shows the important roles of genes containing regions of sequence identity play in the evolution of vertebrates ranging from chromatin remodeling, mitotic cell cycle, signaling pathway, gene switch to signal transduction, cell-cell adhesion and nervous system development.

\section{Phyogenetic analysis}

A screen of vertebrate genomes has unexpectedly exhumed short regions of sequence identity to insect viruses leading us to speculate about the evolutionary relationship among these sequences. And then phyogenetic comparisons of these sequences identity were performed as described in Methods.

\section{Sequence identity to Adoxophyes orana NPV}

Significant blast hits to Adoxophyes orana NPV were sequences from species including mammalian, virus, fungi and bacteria (Figure 2). Sequences from Oryctolagus cuniculus, Cafeteria roenhergensis virus BV-PW1, Penicillium chrysogenum Wisconsin 54-1255, Dictyostelium purpureum and Adoxophyes orana NPV grouped into a single group with robust bootstrap support $(100 \%)$, suggesting that they are likely derived from the same lineage. Cafeteria roenhergensis virus has the largest genome of any described marine virus and infects a widespread marine phagocytic protest [9]. The argument that cafeteria roenhergensis virus belongs to the fourth domain of life is supported by recent study [10].

\section{Sequence identity to Choristoneura occidentalis}

\section{granulovirus}

Sequences matching Choristoneura occidentalis granulovirus were all identified in insects (Figure 3). In phylogenies, these short regions identity grouped into two clades, the largest of which included matches related to insect genomes suggesting that they are from the same ancestral lineage. Sequence derived from Choristoneura occidentalis granulovirus formed a single clade. It's hard for us to know whether sequences from insects originated from distinct Choristoneura occidentalis granulovirus linage or not.

\section{Sequence identity to Culex nigripalpus baculovirus}

We identified high-level significant matches to Culex nigripalpus baculovirus in the genomes of plant, mammalian, insect (Figure 4). Phylogenies constructed grouped Mouse, Drosophila willistoni with Culex nigripalpus baculovirus with a robust support (100\%), suggesting they are likely derived from the same exogenous lineage.

\section{Sequence identity to Cydia pomonella granulovirus}

Significant matches to Cydia pomonella granulovirus are short regions identified in a broad range of lineage genomes including chordate, fungi, insects, vertebrates, protozoa and plant (Figure 5). Curiously, Cyprinus carpio, Mus musculus and Theragra chalcogramma and some other species grouped together into a larger well-surpported clade with Cydia pomonella granulovirus while 
Table 1 Insect viruses and vertebrates sequences, showing the regions of sequence identity (>=28 bp)

\begin{tabular}{|c|c|c|c|c|c|c|c|c|}
\hline Virus Family & $\begin{array}{l}\text { Virus } \\
\text { name }\end{array}$ & $\begin{array}{l}\text { accession } \\
\text { number }\end{array}$ & Animal name & $\begin{array}{l}\text { GenBank accession } \\
\text { number }\end{array}$ & $\begin{array}{l}\text { Nucleotide position of } \\
\text { animals }\end{array}$ & $\begin{array}{l}\text { Length } \\
\text { (bp) }\end{array}$ & $\begin{array}{l}\mathrm{E}- \\
\text { value }\end{array}$ & $\overline{\text { Identity }}$ \\
\hline \multirow[t]{48}{*}{ Baculoviridae } & CuniNPV & NC_003084 & Mouse & NW_001030773.1 & $2590199-2590237$ & 39 & $1 \mathrm{e}-4$ & $95 \%$ \\
\hline & & & Rat & NW_047339.1 & $3135495-3135526$ & 32 & $4 e-4$ & $100 \%$ \\
\hline & & & & NW_001084656.1 & $73274015-73274046$ & 32 & $4 e-4$ & $100 \%$ \\
\hline & ChocGV & NC_008168 & Chicken & NW_001471682.1 & 139049-139125 & 77 & $8 e-20$ & $92 \%$ \\
\hline & & & & NW_001471533.1 & 8588-8682 & 59 & $8 e-20$ & $89 \%$ \\
\hline & & & & & $11486-11562$ & 77 & $4 e-18$ & $91 \%$ \\
\hline & & & $\begin{array}{l}\text { western clawed } \\
\text { frog }\end{array}$ & NW_003173493.1 & $56-150$ & 95 & $5 e-23$ & $91 \%$ \\
\hline & & & & NW_003170485.1 & $154-248$ & 95 & $5 e-23$ & $91 \%$ \\
\hline & & & & NW_003170383.1 & $2710-2804$ & 95 & $5 e-23$ & $91 \%$ \\
\hline & & & & NW_003167681.1 & $7042-7136$ & 95 & $5 e-23$ & $91 \%$ \\
\hline & & & & NW_003165127.1 & 14113-14207 & 95 & $5 e-23$ & $91 \%$ \\
\hline & & & & NW_003164260.1 & $65463-65557$ & 95 & $5 e-23$ & $91 \%$ \\
\hline & & & & NW_003170529.1 & $87-180$ & 95 & $2 e-21$ & $89 \%$ \\
\hline & & & & & $2395-2471$ & 77 & $5 e-18$ & $91 \%$ \\
\hline & & & & NW_003168613.1 & $7284-7360$ & 77 & $5 e-18$ & $91 \%$ \\
\hline & & & zebra finch & NW_002197778.1 & 10813-10907 & 95 & $4 e-23$ & $91 \%$ \\
\hline & & & & & $881-957$ & 78 & $1 e-14$ & $88 \%$ \\
\hline & & & & NW_002222303.1 & $4415-4509$ & 95 & $2 e-21$ & $89 \%$ \\
\hline & & & & NW_002221112.1 & $5155-5249$ & 95 & $2 e-21$ & $89 \%$ \\
\hline & & & & NW_002205312.1 & $1925-2019$ & 95 & $2 e-21$ & $89 \%$ \\
\hline & & & & NW_002197777.1 & $5158-5252$ & 95 & $2 e-21$ & $89 \%$ \\
\hline & & & & NW_002215575.1 & $2342-2433$ & 92 & $4 e-18$ & $88 \%$ \\
\hline & CpGV & NC_002816 & Opossum & NW_001583776.1 & $49362-49401$ & 40 & 0.001 & $93 \%$ \\
\hline & & & Rat & NW_047512.2 & $4126149-4126187$ & 39 & $1 e-4$ & $95 \%$ \\
\hline & & & & NW_001084735.1 & $26022662-26022700$ & 39 & $1 e-4$ & $95 \%$ \\
\hline & & & & NW_047471.2 & $4060358-4060389$ & 32 & $5 e-4$ & $100 \%$ \\
\hline & & & & NW_047801.1 & $6211322-6211356$ & 35 & $5 e-4$ & $97 \%$ \\
\hline & & & & NW_001084717.1 & 537999-538030 & 32 & $5 e-4$ & $100 \%$ \\
\hline & & & & NW_001084876.1 & $27348810-27348844$ & 35 & $5 e-4$ & $97 \%$ \\
\hline & & & Rabbit & NW_003159328.1 & 7491714-7491744 & 31 & $9 e-4$ & $100 \%$ \\
\hline & ChchNPV & NC_007151 & $\begin{array}{l}\text { Sumatran orang- } \\
\text { utan }\end{array}$ & NW_002879912.1 & 596051-596082 & 32 & $4 e-4$ & $100 \%$ \\
\hline & EcobNPV & NC_008586 & mouse & NT_039649.7 & $55558397-55558431$ & 35 & $5 e-4$ & $97 \%$ \\
\hline & & & Marmoset & NW_003184594.1 & $7284126-7284248$ & 124 & $4 e-18$ & $82 \%$ \\
\hline & & & Rat & NW_047689.2 & $35310450-35310491$ & 35 & $5 e-4$ & $97 \%$ \\
\hline & & & & NW_001084827.1 & $32823677-32823711$ & 35 & $5 e-4$ & $97 \%$ \\
\hline & SfMNPV & NC_009011 & Zebrafish & NW_001878120.3 & 69811-69844 & 35 & $5 e-4$ & $97 \%$ \\
\hline & SeMNPV & NC_002169 & Rat & NW_047356.1 & $22195469-22195510$ & 43 & $2 e-4$ & $93 \%$ \\
\hline & & & & NW_001084662.1 & $30770186-30770227$ & 43 & $2 e-4$ & $93 \%$ \\
\hline & LsNPV & NC_008348.1 & Rhesus macaque & NW_001105692.1 & 773081-773115 & 35 & $4 e-4$ & $97 \%$ \\
\hline & & & Opossum & NW_001582020.1 & $41004052-41004090$ & 39 & $1 e-4$ & $95 \%$ \\
\hline & & & Panda & NW_003218644.1 & $263401-263436$ & 36 & $8 e-5$ & $97 \%$ \\
\hline & & & Rat & NW_047829.1 & 1021494-1021528 & 35 & $7 e-4$ & $97 \%$ \\
\hline & & & & NW_047473.1 & $17381564-17381598$ & 35 & $7 e-4$ & $97 \%$ \\
\hline & & & & NW_047711.2 & $25617419-25617456$ & 38 & $7 e-4$ & $95 \%$ \\
\hline & & & & NW_001085491.1 & $25617419-25617456$ & 35 & $7 e-4$ & $97 \%$ \\
\hline & & & & NW_001084718.1 & 16637290-16637324 & 35 & $7 e-4$ & $97 \%$ \\
\hline & & & & NW_001084836.1 & $24037274-24037311$ & 38 & $7 e-4$ & $95 \%$ \\
\hline & MaviMNPV & NC_008725 & Marmoset & NW_003183861.1 & $808726-808762$ & 38 & $9 e-4$ & $95 \%$ \\
\hline
\end{tabular}


Table 1 Insect viruses and vertebrates sequences, showing the regions of sequence identity (> = 28 bp) (Continued)

\begin{tabular}{|c|c|c|c|c|c|c|c|c|}
\hline & PoGV & NC_004062 & $\begin{array}{l}\text { duck-billed } \\
\text { platypus }\end{array}$ & NW_001794503.1 & $629177-629241$ & 67 & $2 e-4$ & $84 \%$ \\
\hline & AdorGV & NC_011423 & Rabbit & NW_003159291.1 & $19601679-19601713$ & 35 & $2 \mathrm{e}-4$ & $97 \%$ \\
\hline & & & & NW_003159237.1 & $33249365-33249399$ & 35 & $2 e-4$ & $97 \%$ \\
\hline & & & & NW_003159323.1 & $30674664-30674697$ & 34 & $8 e-4$ & $97 \%$ \\
\hline & & & & NW_003159357.1 & $771225-771258$ & 34 & $8 e-4$ & $97 \%$ \\
\hline & GflV & NC_008923 & Zebrafish & NW_001878107.3 & 889847-889879 & 33 & $2 \mathrm{e}-4$ & $97 \%$ \\
\hline & & & & & $889234-889261$ & 28 & $7 e-4$ & $100 \%$ \\
\hline & & & & NW_001877665.3 & 641091-641118 & 28 & $7 e-4$ & $100 \%$ \\
\hline & & & & & $965204-965231$ & 28 & $7 e-4$ & $100 \%$ \\
\hline Ascoviridae & TnAV-2C & NC_008518 & $\begin{array}{l}\text { Sumatran orang- } \\
\text { utan }\end{array}$ & NW_002880108.1 & $598679-598717$ & 39 & $4 e-4$ & $95 \%$ \\
\hline \multirow[t]{9}{*}{ Polydnaviridae } & MdBV & NC_007034 & Marmoset & NW_003184482.1 & 2186961-2186992 & 32 & $2 e-5$ & $100 \%$ \\
\hline & & & & NW_003184465.1 & $644797-644825$ & 29 & 0.001 & $100 \%$ \\
\hline & HfIV & NC_008949 & Rhesus macaque & NW_001124102.1 & 1986281-1986308 & 28 & 0.001 & $100 \%$ \\
\hline & CcBV & NC_006651 & $\begin{array}{l}\text { Duck-billed } \\
\text { platypus }\end{array}$ & NW_001753059.1 & $454802-454833$ & 32 & 0.001 & $97 \%$ \\
\hline & & NC_006654 & $\begin{array}{l}\text { Western clawed } \\
\text { frog }\end{array}$ & NW_003163742.1 & $13336070-13336110$ & 30 & $2 e-4$ & $100 \%$ \\
\hline & & NC_006646 & Rat & NW_047553.1 & $6590148-6590200$ & 53 & $6 e-8$ & $91 \%$ \\
\hline & & & & NW_001084751.1 & 4855654-4855706 & 53 & $6 e-8$ & $91 \%$ \\
\hline & CsIV & NC_007989 & Zebra finch & NW_002198116.1 & 15663-15691 & 29 & $4 e-4$ & $100 \%$ \\
\hline & & & & NW_002198283.1 & $2552721-2552749$ & 29 & $4 e-4$ & $100 \%$ \\
\hline \multirow[t]{3}{*}{ Reoviridae } & NLRV & NC_003659.1 & Zebrafish & NW_001877567.3 & $335436-335467$ & 32 & $5 e-4$ & $97 \%$ \\
\hline & FDV & NC_007155 & $\begin{array}{l}\text { Duck-billed } \\
\text { platypus }\end{array}$ & NW_001794408.1 & $3462447-3462475$ & 29 & $2 e-4$ & $100 \%$ \\
\hline & RBSDV & NC_014709 & Horse & NW_001867377.1 & $20656389-20656416$ & 28 & $8 e-4$ & $100 \%$ \\
\hline
\end{tabular}

Mouse, Rattus, Schistoroma mansoni and Drosophila melanogaster as well as Candida albicans grouped into a smaller clade. Considering that a closely related species doesn't group into the same clade, the initial nucleotide sequences flow from Cydia pomonella to the ancestor of the Mus musculus at least post dated the split of Mus musculus and Rattus norvegicus which occurred about 10 million years ago [11].

\section{Sequence identity to Leucania separata}

Matches to Leucania separata were sequences from different species ranging from fungi, mammalians, bacteria

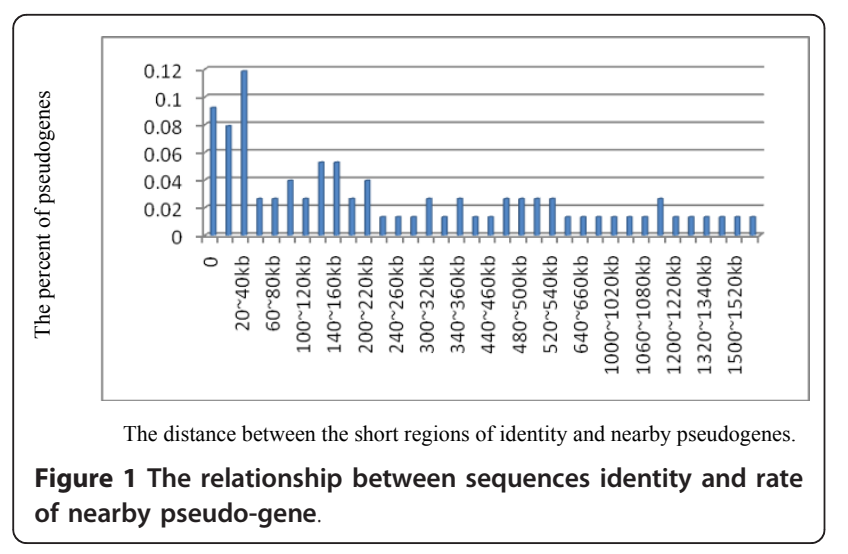

and protozoa as well as insects (Figure 6). Interestingly, with a robust bootstrap support (97\%) sequences from Mouse and Leucania separata grouped into a single group suggesting that they are likely derived from the same ancestral lineage. As for sequences identity from Mus musculus, Rattus norvegicus, fungi and bacteria they may derive from distinct Leucania separata lineages.

\section{Discussion}

In order to broaden the scope of people's understanding of the interaction between virus and animals, We searched genomes of 21 currently available vertebrates for sequences identity to that of insect viruses with expectation that possible sequences identity may exist, and unearthed lush short regions of sequence identity in diverse animals. The chance matches of the search were ruled out by performing reciprocal BLAST. With sequence length from 28 to $124 \mathrm{bp}$, most of them are non-functional, however, with exceptional occasions, some are within exon.

The mechanism that nucleotide sequences flowed from ancestral insect viruses to vertebrates is still unclear. A possible explanation for the phenomenon is due to genetic mobile element such as virus and phage 
Table 2 Biological process or molecular function of the regions of sequence identity products.

\begin{tabular}{|c|c|c|c|c|c|c|c|}
\hline Virus sp & $\begin{array}{l}\text { GenBank } \\
\text { accession } \\
\text { no. }\end{array}$ & $\begin{array}{l}\text { Animal } \\
\text { name }\end{array}$ & $\begin{array}{l}\text { GenBank } \\
\text { accession no. }\end{array}$ & Location & Gene products & Gen ID & $\begin{array}{l}\text { Biological Process or Molecular Function of } \\
\text { products }\end{array}$ \\
\hline \multirow[t]{3}{*}{ CuniNPV } & NC_003084 & Mouse & NW_001030773.1 & intron & Rere & 68703 & $\begin{array}{l}\text { Chromatin remodeling; multicellular orga ismal } \\
\text { development; regulation of transcription, DNA- } \\
\text { dependent }\end{array}$ \\
\hline & & Rat & NW_047339.1 & intron & Psme3 & 287716 & amine metabolic process; oxidation-reduction \\
\hline & & Rat & NW_001084656.1 & intron & Psme3 & 287716 & $\begin{array}{l}\text { process; regulation of ubiquitin-protein ligase } \\
\text { activity involved in mitotic cell cycle; positive } \\
\text { regulation of endopeptidase activity; involved in } \\
\text { mitotic cell cycle }\end{array}$ \\
\hline \multirow[t]{3}{*}{ ChocGV } & NC_008168 & Chicken & NW_001471533.1 & intron & $\begin{array}{l}\text { similar to } \\
\text { neuropeptide }\end{array}$ & 769505 & some enzyme-like catalysis; many are involved \\
\hline & & $\begin{array}{l}\text { Western } \\
\text { clawed } \\
\text { frog }\end{array}$ & NW_003170485.1 & intron & miscRNA & 100487653 & in processing RNA after it is formed; some \\
\hline & & $\begin{array}{l}\text { Western } \\
\text { clawed } \\
\text { frog }\end{array}$ & NW_003170529.1 & intron & miscRNA & 100488236 & $\begin{array}{l}\text { of these small RNAs may serve as switches, turning } \\
\text { genes on and off; RNAi, silence genes by tagging } \\
\text { their mRNA for destruction }\end{array}$ \\
\hline \multirow[t]{4}{*}{ CpGV } & NC_002816 & Rat & NW_047471.2 & intron & Sh3rf1 & 306417 & zinc ion binding \\
\hline & & Rat & NW_001084717.1 & intron & Sh3rf1 & 306417 & \\
\hline & & Rat & NW_047801.1 & intron & Ephb1 & 24338 & axon guidance; camera-type eye morphogenesis; \\
\hline & & Rat & NW_001084876.1 & intron & Ephb1 & 24338 & $\begin{array}{l}\text { central nervous system projection neuron } \\
\text { axonogenesis; cranial nerve axonogenesis; } \\
\text { development; optic nerve morphogenesis; retinal } \\
\text { ganglion cell axon guidance; signal transduction; } \\
\text { transmembrane receptor protein tyrosine kinase } \\
\text { signaling pathway }\end{array}$ \\
\hline EcobNPV & NC_008586 & Marmoset & NW_003184594.1 & intron & $\mathrm{ZC} 3 \mathrm{H} 11 \mathrm{~A}$ & 100412100 & $\begin{array}{l}\text { Metal ion binding; nucleic acid binding; protein } \\
\text { binding; zinc ion binding }\end{array}$ \\
\hline \multirow[t]{2}{*}{ LsNPV } & NC_008348 & $\begin{array}{l}\text { Rhesus } \\
\text { macaque }\end{array}$ & NW_001105692.1 & intron & NFATC1 & 698089 & $\begin{array}{l}\text { Calcium ion transport; epithelial to mesenchymal } \\
\text { transition; G1/S transition of mitotic cell cycle; heart } \\
\text { development; intracellular signal transduction; } \\
\text { positive regulation of transcription from RNA } \\
\text { polymerasell promoter; regulation of transcription, } \\
\text { DNA-dependent }\end{array}$ \\
\hline & & Panda & NW_003218644.1 & intron & CNTN3 & 100473475 & cell-cell adhesion; nervous system development \\
\hline PoGV & NC_004062 & $\begin{array}{l}\text { Duck- } \\
\text { billed } \\
\text { platypus }\end{array}$ & NW_001794503.1 & exon & $\begin{array}{l}\text { similar to } \\
\text { ubiquitin }\end{array}$ & 100078088 & \\
\hline CsIV & NC_007989 & $\begin{array}{l}\text { Zebra } \\
\text { finch }\end{array}$ & NW_002198116.1 & intron & $\begin{array}{l}\text { similar to protein } \\
\text { phosphatase } 1\end{array}$ & 100221684 & \\
\hline NLRV & NC_003659 & Zebrafish & NW_001877567.3 & intron & $\begin{array}{l}\text { suppressor of } \\
\text { tumori- } \\
\text { genicity } 14 \\
\text { protein homolog }\end{array}$ & 557248 & peptidolysis \\
\hline FDV & NC_007155 & $\begin{array}{l}\text { Duck- } \\
\text { billed } \\
\text { platypus }\end{array}$ & NW_001794408 & intron & $\begin{array}{l}\text { similar to } 145 \\
\mathrm{kDa} \text { - nucleolar } \\
\text { protein }\end{array}$ & 100084172 & \\
\hline RBSDV & NC_014709 & Horse & NW_001867377.1 & intron & $\begin{array}{l}\text { similar to early B- } \\
\text { cell factor } 1 \\
\text { isoform } 3\end{array}$ & 100059840 & \\
\hline
\end{tabular}

as well as plasmid. Earlier study shows that viruses move between different biomes and the total number of viruses largely exceeds the number of cells [12]. In our data, short regions of sequence identity to virus is also found in bacteria, for example, in the case of Leucania separata, short region of identity is found in Ajellomyces capsulatus. Besides, short regions of sequence identity in the genomes of bacteria and bacteriophages as well as human were identified recently [13]. And further study is still warranted.

The fate of most acquired nucleotide sequences in the chromosomes of animals has been to undergo deletion due to homologous recombination [14], however, the deletion rate decreased dramatically with age [14], and 


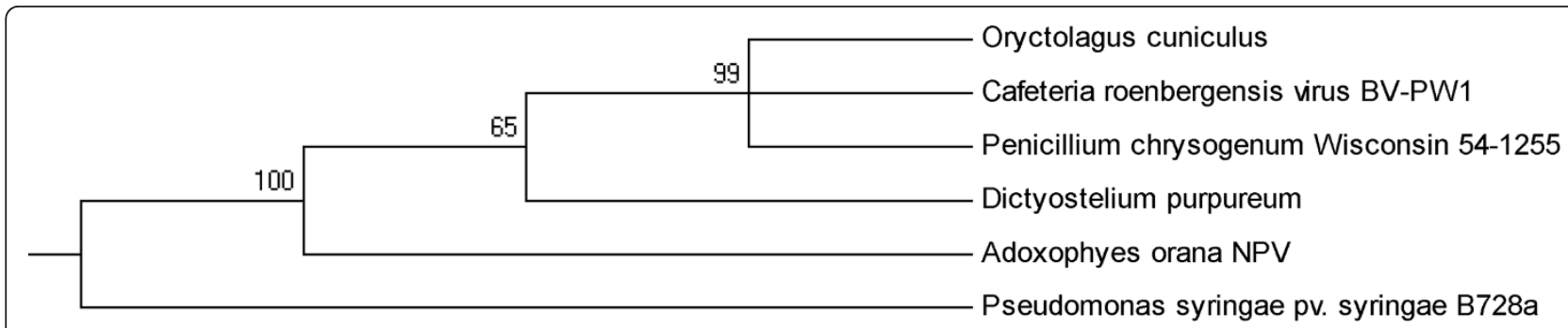

Figure 2 Phylogenetic relationship of short regions of identity to Adoxophyes orana NPV.

finally only few fragments of the sequences fixed into the genomes of germ line cells and passed from parent to offspring vertically. These obtained sequences undoubtedly play a pivotal role in shaping vertebrates genome. Among the products of the short regions of sequence identity, some involve in interaction with animals: chromatin remodeling, regulation of apoptosis, signaling pathway, nerve system development and some enzyme-like catalysis. On one hand, these products take in part in the formation of vertebrate, help to promote the evolution of vertebrates. On the other hand, likewise, these products play an important role in promotion of virus persistence $[5,15]$. For the survival of virus, the ideal can be achieved that the impact of its infection will not harm the host and the risk of host pathology will be reduced with a long-term host [15]. From this aspect, the phenomenon that virus invaded animal(s) and fixed its nucleotide sequences into the genomes of the germ line cells and passed vertically is a typical winwin strategy both for the survival of virus sequences and the long-term evolution of animal(s).

No discussion of short regions of sequence identity would be complete without mention pseudo-genes. Pseudo-gene which is known for non-functional, genelike sequences due to a high mutation rate is harbored by mammalian genomes [16]. Lacking functional promoters or other regulatory elements, a pseudo-gene is not transcribed $[17,18]$. Coincide with the studies that a fixed viral insertion possibly decay into a pseudo-gene $[1,17]$, in our study 7 out of 76 pseudo-genes harbor

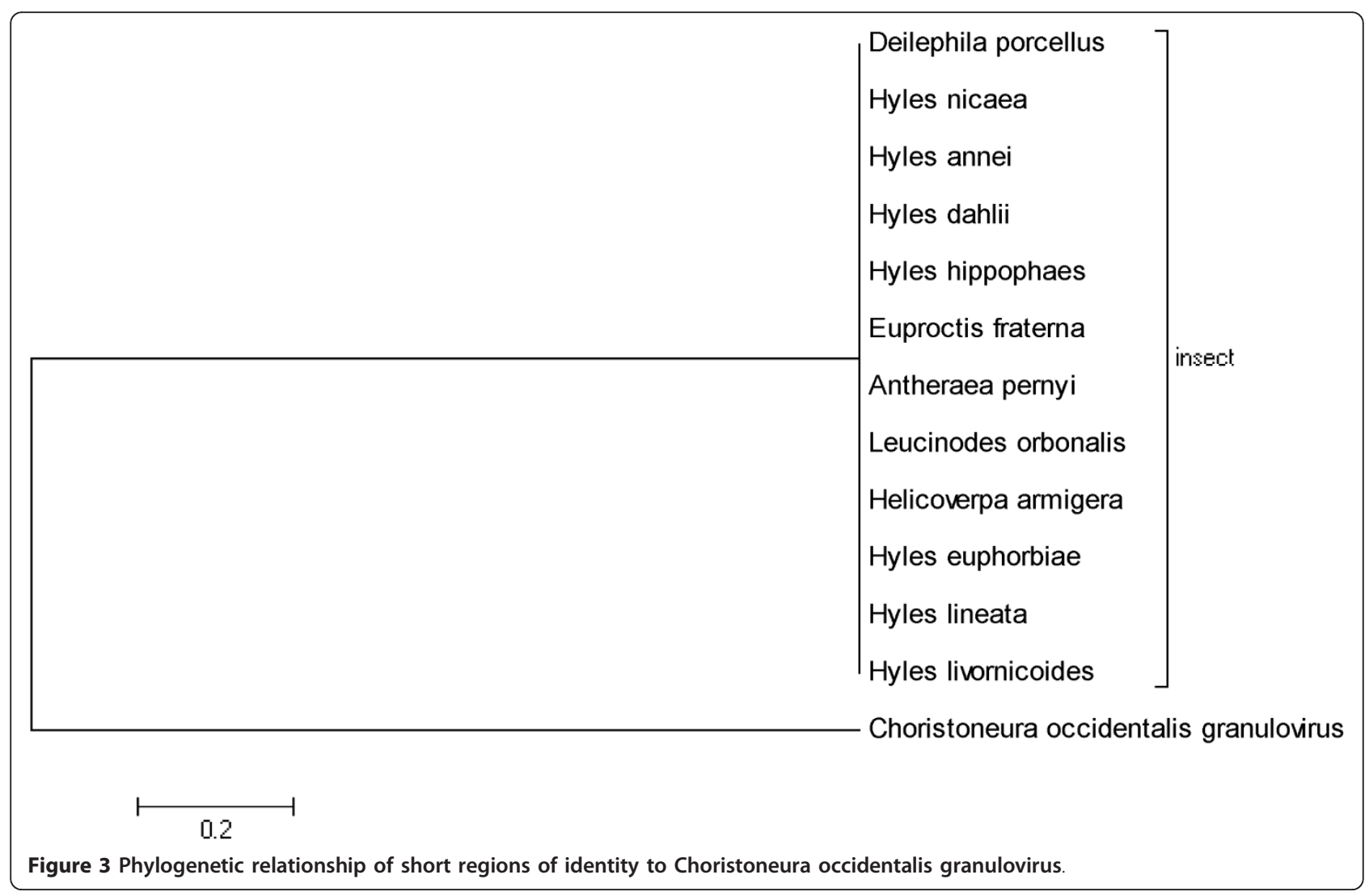




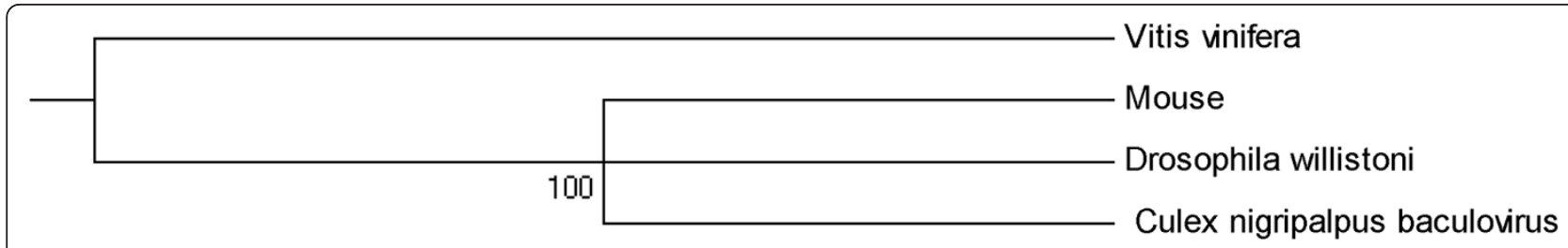

Figure 4 Phylogenetic relationship of short regions of identity to Culex nigripalpus baculovirus.

short regions of sequence identity. However, it is quite confused that dozens of pseudo-genes were located near the short regions identity from several hundred base pair to more than one million base pair. A rough rule is that most of them are within $1 \mathrm{Mb}$. The reason why so many pseudo-genes are located nearby is not clear. The explanation that the distribution of nearby pseudo-genes is by chance seems not likely. The fact that pseudogenes tend to occur in the genome of families with environmental-response functions shows that instead of being dead, they may form a reservoir of diverse "extra part" which can be helpful for an organism to get used to its surroundings [19]. Alternative explanation is that the short regions of sequence identity may function by an unknown regulatory mechanism in the formation of pseudo-genes. Note that in our study, in the case of western clawed frog, short regions identity to Choristoneura occidentalis granulovirus were within intron of the gene whose product is miscRNA. MiscRNA is short for miscellaneous RNA, a general term for a series of miscellaneous small RNA. It serves a variety of functions, including some enzyme-like catalysis and processing RNA after it is formed. Besides, some of these small RNAs may serve as switches. Others, called RNAi,

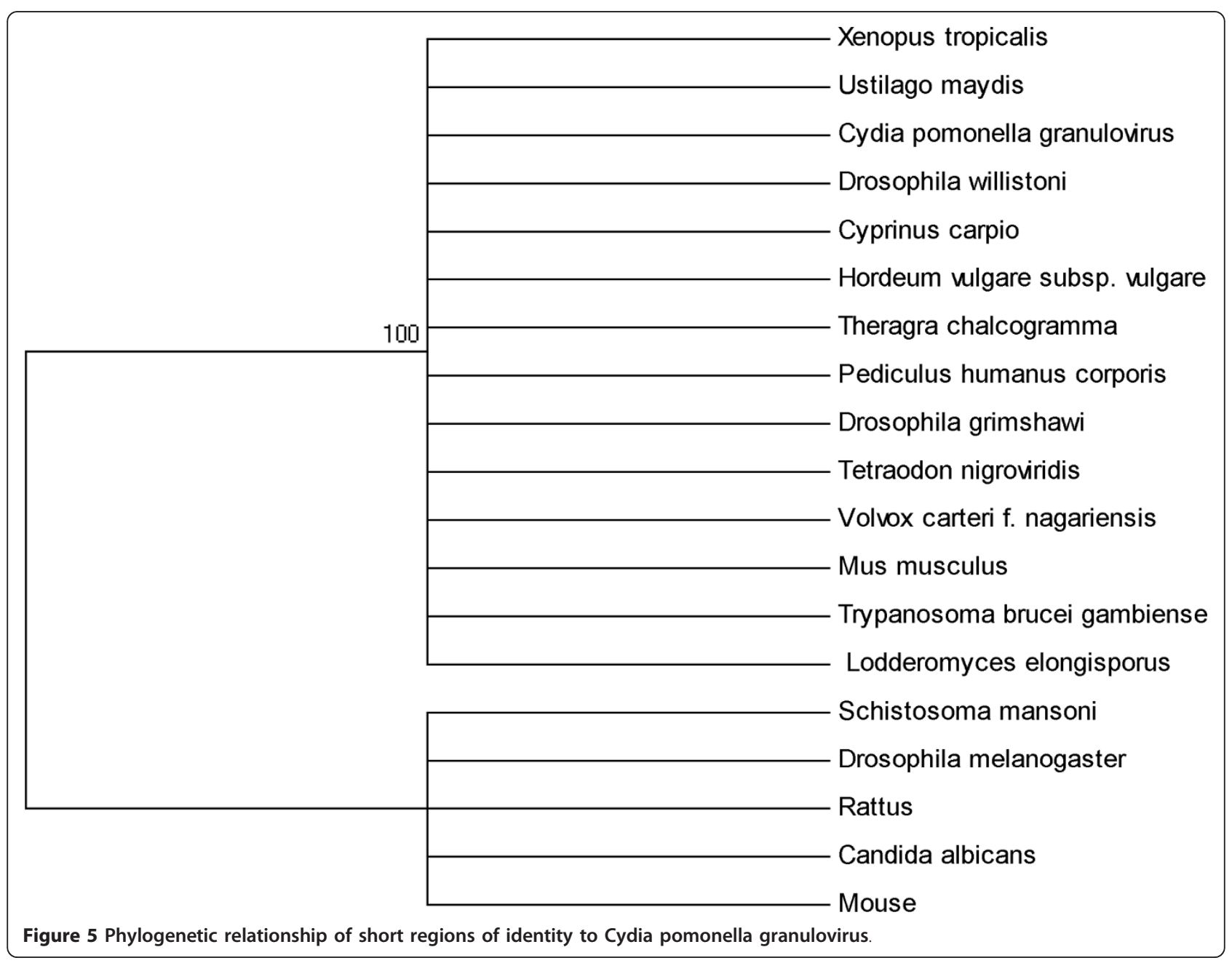




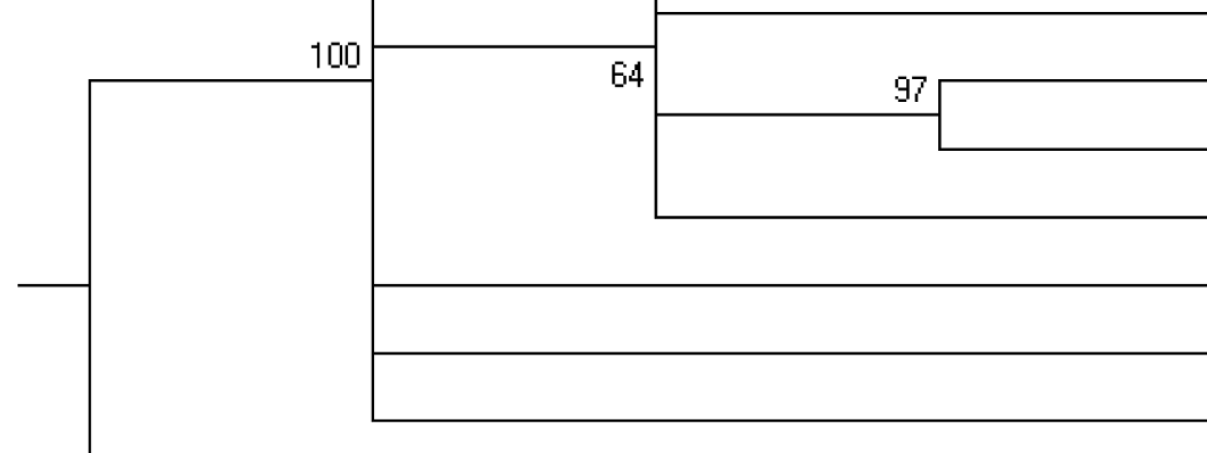
Mouse

Leucania separata

Drosophila grimshawi

Rattus norvegicus

Drosophila melanogaster

Drosophila virilis

Trypanosoma brucei

Figure 6 Phylogenetic relationship of short regions of identity to Leucania separate.

silence genes by tagging their mRNA for destruction $[20,21]$. Maybe some of these small RNAs serve as gene switches, turning genes on and off, or just silence genes with the help of RNAi. Besides, it's known that enhancers as well as other regulatory elements can be $1 \mathrm{Mb}$ from the target gene [22]. The phenomenon that most nearby pseudo-genes are within $1 \mathrm{Mb}$ coincides with the description above. Apparently, further study is needed to address this possibility.

We have investigated the evolutionary radiation of some of the identified short regions of insect viruses and demonstrated a broad history of interaction between insect viruses and vertebrates. It is interesting to speculate that short regions of identity occurred across a brand species. According to our data, at least some short regions of identity identified in vertebrates are derived from insect viruses. And the initial gene flow from Cydia pomonella to the ancestor of the Mus musculus at least post dated the divergence of Mus musculus and Rattus norvegicus about 10 million years ago. However, due to the limited samples, it is hard for us to know whether some sequences identity of the insect viruses and that of vertebrates shared the same ancestral lineage or not. Since the evolution of some viral sequences is more rapid than that of animals, it may mask any two nucleotide sequences which actually derived from the same ancestor [23].

\section{Conclusions}

Our study established that the genetic material derived from insect viruses can flow to vertebrates and play a significant evolutionary role for the development of vertebrates and the survival of the viruses. This win-win strategy may be the result of natural selection.

\section{Methods}

\section{Genome screening}

The genomes of non-retroviral families of insect viruses were screened against chromosome assemblies and whole genome shotgun assemblies of 21 vertebrate species in silico approach using BLASTn with the resources of NCBI. Insect viruses sequences with a high-level identity (i.e. e-value $<0.001$ ) of matches to vertebrates nucleotide sequences were acquired. Then the acquired animal sequences were used as queries to screen the GenBank non-redundant (nr) database in a reciprocal BLASTn search. Significant matches to retroviruses and non-insect viruses were discarded, while the remaining matches were considered as regions of identity to nonretroviral families of insect viruses.

Regions of identity were located in corresponding genome shotgun assemblies of vertebrates precisely. If pseudo-genes were found near regions of identity (i.e. $2000 \mathrm{~kb}$ within their 5' and/or 3' ends) distance was calculated between the nearby pseudo- genes and 5'site and/or 3's site of regions of identity.

\section{Phylogenetic analysis}

For understanding the distribution and possible origin of sequences identity, BLASTn was run with virus sequences as queries to screen the GenBank non-redundant (nr) database. Significant hits with over 95\% 
identity and blast E-values of 10-7 or lower were identified as regions of sequence identity. And representative sequences were extracted. These nucleotide sequences were aligned using ClustalX[24] program and manually edited. Neighbor-Joining (NJ) phylogenies[25] were then constructed using the nucleotide sequence alignments with PHYLIP [26]. A consensus tree was calculated with the program Consensus of the PHYLIP package. Support for the ML trees was evaluated with a total of 1,000 bootstrap replicates.

\section{Vertebrate name}

Mammals: Primates $(=5)$ : Callithrix jacchus (whitetufted-ear marmoset); Homo sapiens (human); Macaca mulatta (rhesus macaque); Pan troglodytes (chimpanzee); Pongo abelii (Sumatran orangutan); Rodents (= 2): Mus musculus (laboratory mouse); Rattus norrvegicus (rat)

Monotremes $(=1)$ : Ornithorhynchus anatinus (duckbilled platypus) Marsupials (=1):Monodelphis domestica (opossum) Other Mammals (= 8): Ailuropoda melanoleuca (giant panda); Bos taurus (cattle); Canis lupus familiaris (dog); Equus caballus (horse); Felis catus (cat); Oryctolagus cunniculus (rabbit); Ovis aries (sheep); Sus scrofa (pig) Other Vertebrates $(=4)$ : Danio rerio (zebrafish); Gallus gallus (chicken); Taeniopygia guttata (zebra finch); Xenopus tropicalis (Silurana) (western clawed frog)

\section{Sequences and accession numbers of insect viruses}

Baculoviridae: Choristoneura fumiferana DEF MNPV [GenBank:NC_005137]; Agrotis segetum granulovirus [GenBank:NC_005839]; Helicoverpa armigera NPV G4 [GenBank:NC_002654]; Orgyia pseudotsugata MNPV [GenBank:NC_001875]; Mamestra configurata NPV-A [GenBank:NC_003529]; Cydia pomonella granulovirus [GenBank:NC_002816]; Spodoptera exigua MNPV [GenBank:NC_002169]; Bombyx mori NPV [GenBank: NC_001962]; Bombyx mandarina NPV [GenBank: NC_012672]; Spodoptera frugiperda MNPV virus [GenBank:NC_009011]; Lymantria xylina MNPV [GenBank: NC_013953]; Mamestra configurata NPV-B [GenBank: NC_004117]; Lymantria dispar MNPV[GenBank: NC_001973]; Epiphyas postvittana NPV[GenBank: NC_003083]; Xestia c-nigrum granulovirus [GenBank: NC_002331]; Autographa californica NPV [GenBank: NC_001623]; Helicoverpa armigera NPV NNg1[GenBank:NC_011354]; Pieris rapae granulovirus[GenBank: NC_013797]; Pseudaletia unipuncta granulovirus [GenBank:NC_013772]; Agrotis segetum NPV [GenBank: NC_007921]; Spodoptera litura granulovirus[GenBank: NC_009503]; Chrysodeixis chalcites NPV [GenBank: NC_007151]; Neodiprion abietis NPV [GenBank: NC_008252]; Neodiprion lecontii NPV[GenBank:
NC_005906]; Cryptophlebia leucotreta granulovirus [GenBank:NC_005068]; Adoxophyes orana granulovirus [GenBank:NC_005038]; Helicoverpa armigera NPV [GenBank:NC_003094]; Rachiplusia ou MNPV[GenBank: NC_004323]; Phthorimaea operculella granulovirus [GenBank:NC_004062]; Spodoptera litura NPV [GenBank:NC_003102]; Culex nigripalpus NPV [GenBank: NC_003084]; Plutella xylostella granulovirus [GenBank: NC_002593]; Heliothis zea virus 1 [GenBank: NC_004156]; Clanis bilineata NPV [GenBank: NC_008293]; Neodiprion sertifer NPV [GenBank: NC_005905]; Trichoplusia ni SNPV [GenBank: NC_007383]; Choristoneura fumiferana MNPV [GenBank:NC_004778]; Helicoverpa zea SNPV [GenBank: NC_003349]; Euproctis pseudoconspersa NPV [GenBank:NC_012639]; Agrotis ipsilon multiple NPV [GenBank:NC_011345]; Orgyia leucostigma NPV [GenBank: NC_010276]; Helicoverpa armigera granulovirus [GenBank:NC_010240]; Ecotropis obliqua NPV [GenBank: NC_008586]; Anticarsia gemmatalis NPV [GenBank: NC_008520]; Choristoneura occidentalis granulovirus [GenBank:NC_008168]; Adoxophyes honmai NPV [GenBank:NC_004690]; Hyphantria cunea NPV [GenBank: NC_007767]; Antheraea pernyi NPV [GenBank: NC_008035]; Spodoptera litura nucleopolyhedrovirus II [GenBank:NC_011616]; Helicoverpa armigera multiple NPV [GenBank:NC_011615]; Adoxophyes orana NPV [GenBank:NC_011423]; Maruca vitrata MNPV [GenBank:NC_008725]; Plutella xylostella multiple NPV [GenBank:NC_008349]; Leucania separata nuclear polyhedrosis virus [GenBank:NC_008348]

Entomopoxvirinae: Amsacta moorei entomopoxvirus 'L' [GenBank:NC_002520]; Melanoplus sanguinipes entomopoxvirus [GenBank:NC_001993] Ascoviridae: Spodoptera frugiperda ascovirus 1a [GenBank: NC_008361]; Diadromus pulchellus ascovirus 4a [GenBank:NC_011335]; Heliothis virescens ascovirus 3e [GenBank:NC_009233]; Trichoplusia ni ascovirus 2c [GenBank:NC_008518] Polydnaviridae: Hyposoter fugitivus ichnovirus [GenBank:NC_008946 NC_008973, NC_008973 NC_009003]; Microplitis demolitor bracovirus [GenBank: NC_007028 NC_007041, NC_007044]; Cotesia congregata virus [GenBank: NC_006638 NC_006640, NC_006649]; Cotesia congregata bracovirus [GenBank:NC_006633 NC_006637, NC_006641 NC_006645,NC_006647, NC_006648, NC_006650 NC_006662]; Campoletis sonorensis ichnovirus [GenBank:NC_007985 NC_008008]; Glypta fumiferanae ichnovirus [GenBank:NC_008837 NC_008894, NC_008896 NC_008910, NC_008912 NC_008928]; Campoletis sonorensis ichnovirus [GenBank:NC_008006, NC_008895, NC_008911] Reoviridae: Southern rice black-streaked dwarf virus [GenBank: NC_014708 NC_014717]; Great Island virus [GenBank: 
NC_014522 NC_014531]; Stretch Lagoon orbivirus [GenBank:NC_012754, NC_012755]; Raspberry latent virus[GenBank: NC_014598 NC_014607 ]; African horsesickness virus [GenBank:NC_005996, NC_006009, NC_006011, NC_006012, NC_006016 NC_006021]; Epizootic hemorrhagic disease virus [GenBank: NC_013396 NC_013405]; Kadipiro virus [GenBank: NC_004199, NC_004205 NC_00421, NC_004212 NC_004216]; Fiji disease virus [GenBank:NC_007154 NC_007163]; St Croix River virus [GenBank: NC_005997 NC_005998]; Operophtera brumata reovirus segment 1 [GenBank:NC_007559]; Mal de Rio Cuarto virus[GenBank:NC_008728 NC_008737]; Eyach virus [GenBank:NC_003696 NC_003707]; Aedes pseudoscutellaris reovirus [GenBank:NC_007666 NC_007674]; Heliothis armigera cypovirus [GenBank: NC_010661 NC_010670]; Yunnan orbivirus [GenBank: NC_007656 NC_007665]; Rice ragged stunt virus [GenBank:NC_003749 NC_003752, NC_003757 NC_003759, NC_003769 NC_003771]; Nilaparvata lugens reovirus [GenBank:NC_003652 NC_003661]; Trichoplusia ni cytoplasmic polyhedrosis virus [GenBank:NC_002557, NC_002559 NC_002562, NC_002564 NC_002567]; Homalodisca vitripennis reovirus [GenBank:NC_012535 NC_012546]; Rice gall dwarf virus [GenBank:NC_009241 NC_009252]; Banna virus [GenBank:NC_004198, NC_004200 NC_004204]; Rice dwarf virus [GenBank:NC_003760 NC_003768, NC_003772 NC_003774 ]; Rice black streaked dwarf virus [GenBank:NC_003728 NC_003737 ]; Lymantria dispar cypovirus1[GenBank:NC_003016 NC_003025]; Cypovirus 14 [GenBank: NC_003006 NC_003015] Birnaviridae: Drosophila x virus [GenBank:NC_004169, NC_004177] Dicistroviridae: Black queen cell virus [GenBank:NC_003784]; Triatoma virus [GenBank: NC_003783]; Drosophila C virus [GenBank:NC_001834]; Kashmir bee virus [GenBank:NC_004807]; Aphid lethal paralysis virus [GenBank:NC_004365]; Cricket paralysis virus [GenBank:NC_003924]; Rhopalosiphum padi virus [GenBank:NC_001874]; Israel acute paralysis virus of bees [GenBank:NC_009025]; Himetobi P virus [GenBank:NC_003782]; Acute bee paralysis virus [GenBank: NC_002548]; Plautia stali intestine virus [GenBank: NC_003779]; Solenopsis invicta virus 1 [GenBank: NC_006559]; Homalodisca coagulata virus-1 [GenBank: NC_008029] Tetraviridae: Euprosterna elaeasa virus [GenBank:NC_003412]; Boolarra virus [GenBank: NC_004142, NC_004145]; Pariacato virus chromosome [GenBank:NC_003691 NC_003692]; Nodamura virus [GenBank:NC_002690 NC_002691]; Black beetle [GenBank:NC_001411, NC_002037]; Macrobrachium rosenbergii nodavirus RNA-2 [GenBank:NC_005095]; Flock house virus [GenBank: NC_004146 NC_004144]
List of abbreviations used

ChchNPV: Chrysodeixis chalcites NPV; SFMNPV: Spodoptera frugiperda MNPV; SeMNPV: Spodoptera exigua MNPV; MaviMNPV: Maruca vitrata MNPV; AdorGV: Adoxophyes orana NPV; GflV: Glypta fumiferanae ichnovirus; TnAV2c: Trichoplusia ni ascovirus 2c; MdBV: Microplitis demolitor bracovirus; HfIV: Hyposoter fugitivus ichnovirus; CcBV: Cotesia congregata bracovirus; CuniNPV: Culex nigripalpus NPV; ChocGV: Choristoneura occidentalis granulovirus; CpGV: Cydia pomonella granulovirus; EcobNPV: Ecotropis obliqua NPV; LsNPV: Leucania separata NPV; PoGV: Phthorimaea operculella granulovirus; CsIV: Campoletis sonorensis ichnovirus; NLRV: Nilaparvata lugens reovirus; FDV: Fiji disease virus; RBSDV: Southern rice black-streaked dwarf virus

\section{Acknowledgements}

The authors have no support or funding to report. The authors thank the Genome Seqeuncing Consortia for vertebrates and all the researchers for the genome of insect viruses.

\section{Author details}

${ }^{1}$ National Center for Clinical Laboratories, Beijing Hospital, Beijing 100730, China. ${ }^{2}$ Graduate School, Peking Union Medical College, Chinese Academy of Medical Sciences, Beijing, 100730, China.

\section{Authors' contributions}

Conceived the experiment: $J$, Designed the experiment: GF; Performed the experiment: GF; Analyzed the data: GF; Wrote the paper: GF; Revised the paper: $J$; gave the final approval of the version to be published: $J$. Both authors read and approved the final manuscript.

\section{Competing interests}

The authors declare that they have no competing interests.

Received: 3 July 2011 Accepted: 10 November 2011

Published: 10 November 2011

\section{References}

1. Feschotte C: Virology: Bornavirus enters the genome. Nature 463:39-40.

2. Horie M, Tomonaga $\mathrm{K}$ : [Endogenous bornavirus elements in mammalian genome]. Uirusu 60:143-153.

3. Horie $M$, Honda $T$, Suzuki $Y$, Kobayashi $Y$, Daito $T$, Oshida T, Ikuta K, Jern P, Gojobori T, Coffin JM, Tomonaga K: Endogenous non-retroviral RNA virus elements in mammalian genomes. Nature 463:84-87.

4. Herrera RJ, Lowery RK, Alfonso A, McDonald JF, Luis JR: Ancient retroviral insertions among human populations. J Hum Genet 2006, 51:353-362.

5. Kerr JR, Boschetti N: Short regions of sequence identity between the genomes of human and rodent parvoviruses and their respective hosts occur within host genes for the cytoskeleton, cell adhesion and Wnt signalling. J Gen Virol 2006, 87:3567-3575.

6. McFadden G, Murphy PM: Host-related immunomodulators encoded by poxviruses and herpesviruses. Curr Opin Microbiol 2000, 3:371-378.

7. Dunlap KA, Palmarini M, Varela M, Burghardt RC, Hayashi K, Farmer JL, Spencer TE: Endogenous retroviruses regulate periimplantation placental growth and differentiation. Proc Natl Acad Sci USA 2006, 103:14390-14395.

8. Lin GG, Li JM: Sequence identity between the genomes of humans and viruses. Intervirology 2009, 52:196-200.

9. Fischer MG, Allen MJ, Wilson WH, Suttle CA: Giant virus with a remarkable complement of genes infects marine zooplankton. Proc Natl Acad Sci USA 107:19508-19513.

10. Colson P, Gimenez G, Boyer M, Fournous G, Raoult D: The giant Cafeteria roenbergensis virus that infects a widespread marine phagocytic protist is a new member of the fourth domain of Life. PLoS One 6:e18935.

11. McKenzie M, Trounce I: Expression of Rattus norvegicus mtDNA in Mus musculus cells results in multiple respiratory chain defects. J Biol Chem 2000, 275:31514-31519.

12. Breitbart $M$, Rohwer F: Here a virus, there a virus, everywhere the same virus? Trends Microbiol 2005, 13:278-284.

13. LiU Y, Li J: Short regions of sequence identity between the genomes of bacteria and human. Curr Microbiol 62:770-776.

14. Belshaw R, Watson J, Katzourakis A, Howe A, Woolven-Allen J, Burt A, Tristem M: Rate of recombinational deletion among human endogenous retroviruses. J Virol 2007, 81:9437-9442. 
15. Chaston TB, Lidbury BA: Genetic 'budget' of viruses and the cost to the infected host: a theory on the relationship between the genetic capacity of viruses, immune evasion, persistence and disease. Immunol Cell Biol 2001, 79:62-66.

16. Zhang Z, Carriero N, Gerstein M: Comparative analysis of processed pseudogenes in the mouse and human genomes. Trends Genet 2004, 20:62-67.

17. Deininger PL, Moran JV, Batzer MA, Kazazian HH Jr: Mobile elements and mammalian genome evolution. Curr Opin Genet Dev 2003, 13:651-658.

18. Mighell AJ, Smith NR, Robinson PA, Markham AF: Vertebrate pseudogenes. FEBS Lett 2000, 468:109-114.

19. Harrison PM, Gerstein M: Studying genomes through the aeons: protein families, pseudogenes and proteome evolution. $J \mathrm{Mol}$ Biol 2002, 318:1155-1174.

20. Ortiz-Quintero B: [RNA interference: from origins to a novel tool for gene silencing]. Rev Invest Clin 2009, 61:412-427.

21. Vaishnaw AK, Gollob J, Gamba-Vitalo C, Hutabarat R, Sah D, Meyers R, de Fougerolles T, Maraganore J: A status report on RNAi therapeutics. Silence 1:14.

22. Gentles AJ, Wakefield MJ, Kohany O, Gu W, Batzer MA, Pollock DD, Jurka J: Evolutionary dynamics of transposable elements in the short-tailed opossum Monodelphis domestica. Genome Res 2007, 17:992-1004.

23. Holzerlandt R, Orengo C, Kellam P, Alba MM: Identification of new herpesvirus gene homologs in the human genome. Genome Res 2002, 12:1739-1748.

24. Larkin MA, Blackshields G, Brown NP, Chenna R, McGettigan PA, McWilliam H, Valentin F, Wallace IM, Wilm A, Lopez R, et al: Clustal W and Clustal X version 2.0. Bioinformatics 2007, 23:2947-2948.

25. Pearson WR, Robins G, Zhang T: Generalized neighbor-joining: more reliable phylogenetic tree reconstruction. Mol Biol Evol 1999, 16:806-816.

26. J F: PHYLIP (Phylogeny Inference Package), version 3.69. Department of Gnome Sciences and Department of Biology University of Washington 2009.

doi:10.1186/1743-422X-8-511

Cite this article as: Fan and Li: Regions identity between the genome of vertebrates and non-retroviral families of insect viruses. Virology Journal 2011 8:511.

\section{Submit your next manuscript to BioMed Central} and take full advantage of:

- Convenient online submission

- Thorough peer review

- No space constraints or color figure charges

- Immediate publication on acceptance

- Inclusion in PubMed, CAS, Scopus and Google Scholar

- Research which is freely available for redistribution

Submit your manuscript at www.biomedcentral.com/submit 